\title{
Potentials of Processed Termite as a Stabilizing Agent in Clay Soil
}

\author{
Samuel Assam ${ }^{1}$, Fidelis Okafor ${ }^{2}, \mathrm{Umoh}_{\mathrm{Umoh}}^{3}$ \\ Department of Civil Engineering, University of Uyo, Nigeria
}

\begin{abstract}
Expansive soil causes problem on civil engineering structures due to its tendency to swell when it is in contact with water and shrinks when they dry out. Stabilization using chemical admixtures is the oldest and popular method of soil improvement. In this study, an investigation was conducted to explore the possibility of using termite dust as stabilizing admixture to improve clay soils. This investigation involves the determination of the swelling potential of clay soil in its natural state as well as when mixed with vary proportion of termite dust from (0 to 30\%). The termite dust in this experimental work is obtained from termite mound (anthill), dried and ground followed by sieving through sieve no.36. Consistency limits, specific gravity, swelling properties were determined for the samples. Addition of termite dust decreases liquid limit, plasticity index, plastic limit. shrinkage limit, shrinkage index, specific gravity and activity. Also, the experimental results showed that the swelling percentage decreases and rate of swell increases with increasing percentage of termite dust in clay soils. The rates of swelling and swelling percentage of the stabilized specimens were also affected by curing in a positive direction such that the effectiveness of the stabilizer increases with increasing amount-of stabilizer. The $C B R$ and UCS values obtained also increases with increased percentage of stabilizer. From the research findings, it can be deduced that termite dust at 25\%-30\% stabilization can be recommended for use in sub-grade pavement layer in road work.
\end{abstract}

Keyword: Soil Stabilization, Swelling potentials, Rate of Swell, Clay Soil, Processed Termite and Scheffe's Model of Scond Degree Polynomials.

\section{Introduction}

Stabilization refers to the treatment of soil or gravel in order to improve its stability an bearing capacity. Stabilization can be traced as far back as 2000 years ago when the Romans first used a form of lime treatment for their tracks that carried heavy transport wagons. This process is therefore as old as the road construction industry and will continue to be a relevant one for as long as good quality and cheap road aggregates remain scarce. A review of previous works shows that stabilization research efforts have been centred more on traditional than their non-traditional counterpart chemical stabilizers. Some termites are dated as old as 400 years, so base on this fact, this study has come to analyze the unique technology of using processed termites to improve lateritic clay soils

\section{Termites}

Termites, often misnamed white ants, are small to medium-sized, soft-bodied insects which range in color from dull white to light and dark brown, and belong to the insect order lsoptera. Termites also exhibit polymorphism, and a well-defined grouping of individuals into different functional castes, viz. larvae, workers, pseudergates, soldiers, nymphs and reproductives. Of these, the first four are non-winged and incapable of reproduction. Pseudergates retain their ability to differentiate and nymphs develop to alated reproductives.

Termites are social insects belonging to order Isoptera considered to be of the cockroach order Blattodea whose diversity and classification are described in Eggleton (2011). with over 2600 known specifies (Eggleton, 2011); termites are classified into seven families namely (Lo and Eggleton, 2011):

i) Mastotermitidae: This is the most primitive family with only one wood-feeding termite species recorded in Australia.

ii) Kalotermitidae: These consume materials from dry wood

iii) Termopsidae: these nest in and feed on wet dead logs

iv) Hodotermitidae: they are commonly referred to as grass-harvesters

v) Rhinotermitidae: this is a wood consuming family commonly located in the temperate zones.

vi) Seritermitidae: these have few species known and only found in SouthAmerica. They could therefore be classified within the Rhinotermitidae family

vii) Termitidae: Is the largest family, consisting of approximately 2000 species and accounting for almost $75 \%$ of all known termites.

Termite clay is obtained from termite mound, while mound is a pile of earth made by termite resembling a small hill. It is made of clay whose plasticity has further been improved by the secretion from the 
termite while being used in building the mound. Minjinyawa et al (2007). It is therefore a better material than the ordinary clay in terms of utilization for moulding laterite bricks Odamodu (1999) and this type of clay has been reported to perform better than ordinary clay in dam construction Yohanna et al (2003). The clay from the termite mound is capable of maintaining a permanent shape after moulding because of its plasticity; it is also less prone to crack when compared with ordinary clay. In addition, it has low thermal conductivity and expectedly reduced solar heart flow and temperature fluctuation within an enclosure Minjinyawa et al (2007)

Nests

Since termites have a soft cuticle and are easily desiccated; they live in nests that are warm, damp, dark, and sealed from the outside environment. These nests are constructed by workers or old nymphs. The high relative humidity in the interior of the nest (90 to 99 percent) probably is maintained in part by water production resulting from metabolic processes of individual termites.

\section{Nest construction}

Some termites build nests in wood, some in trees and posts, and some below the ground. Although MS and MS begin nests below ground, they form large mounds or towers of soil. The nest is constructed of sand and clay. The workers burrow into the subsoil bringing back a sand grain and a "mouthful" of clay which becomes moistened with saliva. The sand particle is stuck in position in the nest and cemented with the mortar of day and saliva. Building activities are most $\mathrm{W}$ intense at the beginning of the wet season.

Studies showed that an individual termite would pick up a soil pellet of approximate area $10^{-6} \mathrm{~m}^{2}$, crush and masticate it by the buccal appendices and the mandibles and in the process saliva is added. During the study, groups of termite workers of different sizes were observed around a queen and found that individual termites pick up a piece of soil near the queen, transport the pellet to the site of deposition (at a distance of about 2 to 5 $\mathrm{cm}$ from the queen) where they deposit and cement the pellet. This leads to the construction of pillars or columns that are lengthened until they reach a height of 0.5 to $0.8 \mathrm{~cm}$, when workers start to build lamellae which are extended and connected to one another to form a roof over the queen.

Some termite classes utilize faeces in the construction of mound material. These faeces are used to cement and stick in position sand grains in the mound.

\section{Nest structural stability}

In soils, stability is usually a function of the organic (largely polysaccharide and glycoprotein) content of the micro and macro aggregates and of the availability multivalent cations. The following are sources of structural strength in termite mounds according to literature.

- Termites use their saliva to break down cellulose to polysaccharides and finally to glucose.

- The increase of polysaccharide within soil matrix is associated with increase in soil stability. It is therefore possible that the broken down polysaccharide is a primary strength additive to mound soils.

- The presence of enzyme activity in the saliva including .Endo Beta 1,4 Glucanase among others are additional contributors to termitarium strength. Endo-beta 1,4 glucanase digests cellulose to beta glucans which have proved to be effective in soil stability according to a study in Korea. In this study, a purified biopolymer ( $\beta-1,3 / 1,6$-glucan) was used as an engineered soil additive to ordinary residual soil. Micro (i.e., small strain) geotechnical properties of ( $\beta-1,3 / 1,6$-glucan-treated Korean residual soil were measured via non destructive laboratory tests. The results showed that shear modulus increased as the ( $\beta-1,3 / 1,6$-glucan content in soil increases. Meanwhile, $(\beta-1,3 / 1,6$-glucan treatment had no effect on the compression stiffness of soil.

- Although soil organic matter (SOM) is usually considered as a cement ensuring the soil structural stability of mound soil, studies that SOM has a negligible role and that clay can be considered as a key component to understand the structural stability of macroterme mound soil. Additionally, reports indicate that there is a significant increase of clay content in termite mound soil compared to organic matter.

- Withstanding this, some scholars have argued that complex carbohydrates exist in the termite mouth in form of mucopolysacharides. These are believed to enhance the gluing properties of the soil hence making it harder.

\section{Soil Strengthening Mechanism of Termites}

Termites have been known to construct termite mounds using soils which is a result of decomposition of dead plants and animals. The dry matter of plants or plant biomass is generally referred to as Lignocellulose. This is the most abundant biomass on earth commonly composed of cellulose, hemicelluloses and lignin. It is through the digestion of lignocellulose that biomass is converted into biofuels, hence recognized as a potential sustainable source of biofuels and biomaterials production (Himmel et aL, 2007; Ragauskas et al., 2006). The 
study of termites, which have been known to decompose liginocellulose have identified numerous cellulose hydrolysis enzymes (Kudo, 2009; Ohkuma, 2003; Yamada et aL, 2005).

\section{Major findings related to Engineering Properties}

This review has alluded to fundamental aspects of termite mound building. The building behavior of termite workers is a step by step process and motivated by the need to protect the queen while providing shelter and protection for each other. The process of picking up a soil pellet, transporting it to the site of deposition and cementing the pellets together seems to be a logical process following a critical path of controlled activities. That Termites start by constructing pillars (or columns) that are lengthened until they are approximately 0.s$0.8 \mathrm{~cm}$ in height and then build lamellae which are extended and connected to one another to form a roof over the queen while Inter-pillar spaces are also filled with pellets to produce walls. This is a typical construction procedure similar to that developed and being utilized by man.

In a study carried out by Millogo et aI., (2011), it was discovered that the termite mound is composed of $46 \%$ sand, $44 \%$ silt and $10 \%$ clay, was of medium plasticity (Santos, 1989), and could not be adequately shaped by extrusion. For mounds shaping, it is asserted that, termites resort to their saliva (Hesse, 1955) and gather different shaped pellets $(5-1000 \mu \mathrm{m}$ in size), consisting of organic matter, minerals or both (Eschenbrenner, 1986 ). These micro-aggregates represent the basic 'building blocks' of the mound. The measured magnitudes of compressive and bending strengths of nest building samples were s.1 \pm 0.3 and $1.3 \mathrm{MPa}$, respectively, and were found to be as strong as cement-stabilized crude bricks (Azeredo et aI., 2007; Venkatarama and Gupta, 2005). The linear shrinkage of nest soil test-pieces was found to be $<5 \%$ as a result of the presence of a significant amount of fillers (principally quartz.)" and possibly due to the absence of swelling day minerals. Anusha et aI., (2010) studied the surrounding soil sample and termite mound (Mound soil) and the following were noted:

\section{Natural Water Content}

Two soil sample pairs were collected during summer season and a set of three sample pairs during rainy season. The first two samples had an increase in water content for the mound soil possibly due to: (i) Presence' of organic content, (ii) increase in day content, (iii) higher percentage of clanical/enzymes in the mound soil and (iv) presence of finer soil partides.

\section{Organic Content}

(Organic content was determined using the hydrogen peroxide method. It was observed that the percentage of organic content for mound soils and the nearby soil is higher when compared to other oormal soils. Comparing the mound soil and the nearby soil, the reduction in organic content of mound soil may be due to the decomposition of organic matter by the action of termites.

\section{Liquid Limit}

The liquid limit results showed that mound soil had values greater than that of Ssoil in all the cases. This increase in liquid limit for the mound soil may ascribed to: (i) presence of organic content, (ii) increase in day content, (iii) higher percentage of chemical/enzymes in the mound soil and (iv) presence of finer soil partices. And the increase in water content of the surrounding soil in the other three samples is due to the impermeability of mound soil compared to the surrounding soil.

\section{Plastic limit}

The plastic limit test was conducted according to ASTM (0424-59). The plastic limit values show that because the day content of the mound soil is more than the surrounding surface soil; its plastic limit value is also higher.

\section{Plasticity Index}

Considering the plasticity index values, the mound soils have higher plasticity indices than the surrounding soil, which indicate that they have higher clay fractions, hence an increase in cohesion. The other reasons for the increase in the plasticity values of the- mound soil are the higher percentage of chemical/enzymes of termites, organic content and the day content

\section{Specific Gravity}

The specific gravity values of all soil samples are less compared to normal soils found in the corresponding region. Generally reduction of specific gravity is mainly due to the presence of high organic content and lesser amount of iron content. 
To measure the $\mathrm{pH}$ of the soil, 109 sample mixed with $100 \mathrm{~m} 1$ of distilled water standing 24 hours. $\mathrm{pH}$ of the soil was determined using a digital $\mathrm{pH}$ meter. All the samples were acidic, mound soil being less acidic compared to the controls.

It is important and reasonable that, studies regarding the problem of clay soils become imperative day by day if the durative deficit of the world resources and economy is taken into consideration. When geotechnical engineers are faced with clay soils, the engineering properties of these soils need to be improved to make them suitable for construction. Okafor, et al, (2009) and Muntohar et al, (2000)

To study the model of strength determination of soil to the processed termite stabilized soil using Scheffe's second degree polynomials, to check the empirical models results and compare it to the experimental results in the absence of strenuous laboratory results, to check the unconfined compressive strength of processed termite and the CBR values of clay soil. The purpose of this experimental study is to investigate the potentials of processed termite as a stabilizing agent for clay soil.

\section{Materials And Method}

The processed termite for this experimental study was obtained from anthill (mound) in Useoffot Nwaniba, Uyo - Akwa Ibom State.

It was dried and ground to pass through sieve no 36 before usage. The finishing by product is the processed termite whose specific gravity is 0.39 and $\mathrm{pH} 8.14$. The soil sample used was collected in bags by method of disturbed sampling at average depth of (300 -400)mm along Ntak Inyang Road, Itu, Akwa Ibom State. The preliminary tests for identification of till' natural soil and the geotechnical properties of the soil treated with termite dust were carried out in accordance with BS 1377. The Standard Proctor energy level was used for compaction test which was also used to determine the moisture content for CBR and UCS specimens. Processed termite was thoroughly mixed with pulverized soil and then with distilled water

\section{Results And Discussion}

Table 1: Result of Chemical Analysis of Processed Termite

\begin{tabular}{|l|l|l|l|l|l|l|l|l|}
\hline Oxides & $\mathrm{CaO}$ & $\mathrm{SiO}_{2}$ & $\mathrm{Al}_{2} \mathrm{O}_{3}$ & $\mathrm{~K}_{2} \mathrm{O}$ & $\mathrm{Na}_{2} \mathrm{O}$ & $\mathrm{Fe}_{2} \mathrm{O}_{3}$ & $\mathrm{MgO}$ & LOI \\
\hline Processed Termite (\%) & 5.04 & 56.08 & 29.82 & 0.75 & 0.94 & 8.90 & 0.03 & 5.02 \\
\hline Clay (\%) & 0.95 & 48.13 & 18.90 & 1.05 & 1.45 & 14.30 & 0.49 & 21.37 \\
\hline
\end{tabular}

\section{Identification of Soil and Processed Termite}

The result in Table 1, shows the combined percentage of $\mathrm{SiO}_{2}, \mathrm{AI}_{2} \mathrm{O}$ and $\mathrm{Fe}_{2} \mathrm{O}_{3}$, to be 94.8 which satisfies the ASTM requirement of pozzolanic material, of minimum of $70 \%$. $\mathrm{MgO}$ composition was found to be 0.03 which is less than $4 \%$ maximum requirement, while $\mathrm{CaO}$ composition was $5.04 \%$ and is within the recommended range of ASTM C618-78. The loss on ignition showed the extent of carbonation in sample of termite dust during the test, the value obtained was $5.02 \%$ which is less than $7 \%$ maximum required for pozzolan It means that most of the sample where absorbed by the system and the sample contains very little carbon. The composition of the silica alone in $56.08 \%$ and is responsible for the ion exchange between soil and the termite dust resulting in the formation of more granular material and strength development. The index properties of the natural soil before addition stabilizer (processed termite) are shown in Table 2. The geotechnical properties of the natural soil showed that it has a liquid limit and plasticity index of $49.57 \%$ and $18.07 \%$ respectively and classified as A-7-6 in the AASHTO classification system. In its natural state, the soil is not suitable for use as filled material but requires some level of improvement for it to be used as subgrade material based on Nigeria General Specification for Road and bridge Work. Federal Ministry of Work and Housing, (1977).

Table 2: Index Properties of Natural Soil Sample

\begin{tabular}{|c|c|c|c|c|c|c|c|c|c|}
\hline $\mathrm{LL}$ & PL & PI & $\begin{array}{l}\text { Percentage } \quad \text { Passing } \\
\text { Sieve } 200\end{array}$ & $\begin{array}{l}\mathrm{MDD} \\
\left(\mathrm{gm} / \mathrm{cm}^{3}\right)\end{array}$ & $\begin{array}{l}\mathrm{OMC} \\
(\%)\end{array}$ & $\begin{array}{l}\mathrm{UCS} \\
\left(\mathrm{KN} / \mathrm{m}^{2}\right)\end{array}$ & $\begin{array}{l}\text { CBR } \\
\text { Soaked }(\%)\end{array}$ & $\begin{array}{l}\text { CBR } \\
\text { Unsoaked (\%) }\end{array}$ & $\mathrm{G}_{\mathrm{s}}$ \\
\hline
\end{tabular}

\section{Compaction Characteristics}

The relationship between MDD and termite dust content is shown in Figure 7. I he results indicate that from $0 \%$ to $30 \%$ termite dust content, the MDD increased from $1.39 \mathrm{Kg} / \mathrm{m}^{3}$ to $1.78 \mathrm{~K} 1 \mathrm{~m}^{3}$ respectively. This was as a result of termite dust occupying the void within the "nil matrix. It may also be due to the relatively lower specific gravity of processed termite (0.19) to that of the soil (2.19).

Figure 6 shows the variation of OMC with termite dust content. The result shows that the OMC increased with increase in termite dust content. The increase may be attributed to the additional water molecule 
needed to coat the surface area and to lubricate the entire matrix for hydration process. Eze-Uzomaka et al (2010)

\section{Consistency Limits}

Variation of liquid limit with termite dust is shown in Figure 2. The liquid limit decreased with the addition of termite dust from $0 \%$ to $30 \%$. The decrease may be as a result or the calcium silicate present in the termite dust due to high content of silicon (iv) oxide which reacted with the hydroxide in the clay thereby helping in the flocculation and aggregation ul the soil particles.

Figure 1 shows the relationship between plastic limit and termite dust added sample. The trend is similar to that of the liquid limit. The reason for the variation of the liquid limit with termite dust added sample is also similar to that of the variation of plastic limit with termite dust added sample.

Plasticity index and termite dust added sample relationship is shown in Figure 3. The plasticity index decreases from $18.07 \%$ to $8.60 \%$ with increase in termite dust added sample from $0 \%$ to $30 \%$. The reason may be as a result of the replacement of the finer soil particles by termite dust with subsequent reduction in plasticity index. Okafor et al (2009).

\section{California Bearing Ratio}

Figure 8 shows the relationship between the CBR and termite dust added sample at opumurn moisture content. The result shows that the CBR for unsoaked sample increased from $25.40 \%$ to $53.45 \%$ with increase in termite dust content from $0 \%$ to $30 \%$ respectively. The reason for the increment in CBR may be attributed to the gradual formation of' calcium silicate compounds in the termite dust reacting with some calcium hydroxides present in the soil the trend of the soaked CBR was similar to the unsoaked though with lower values. The CBR is a measure of the strength of subgrade.

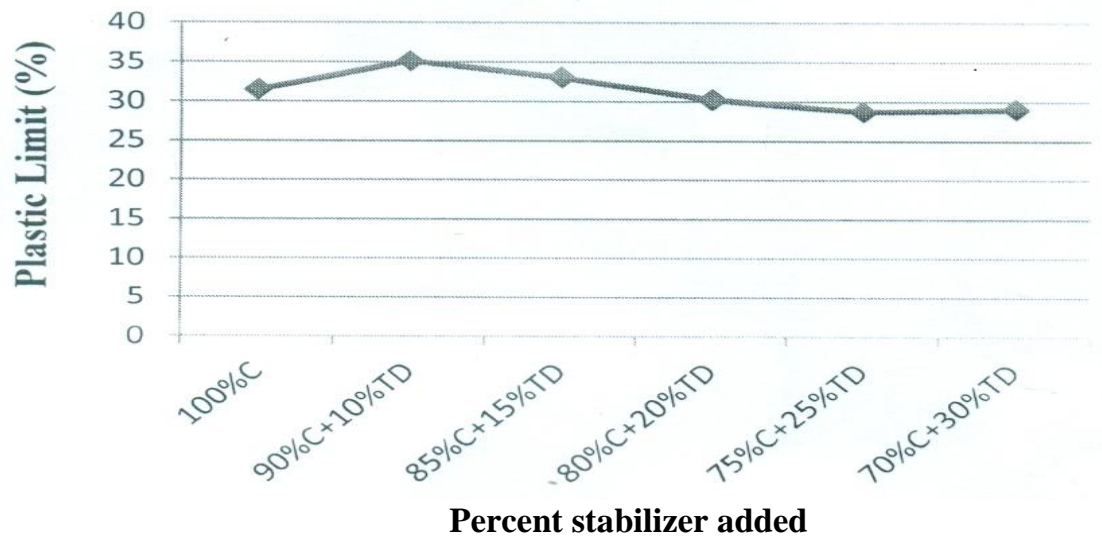

Fig. 1: Effect of Processed Termite on the plastic Limit Value of Sample C

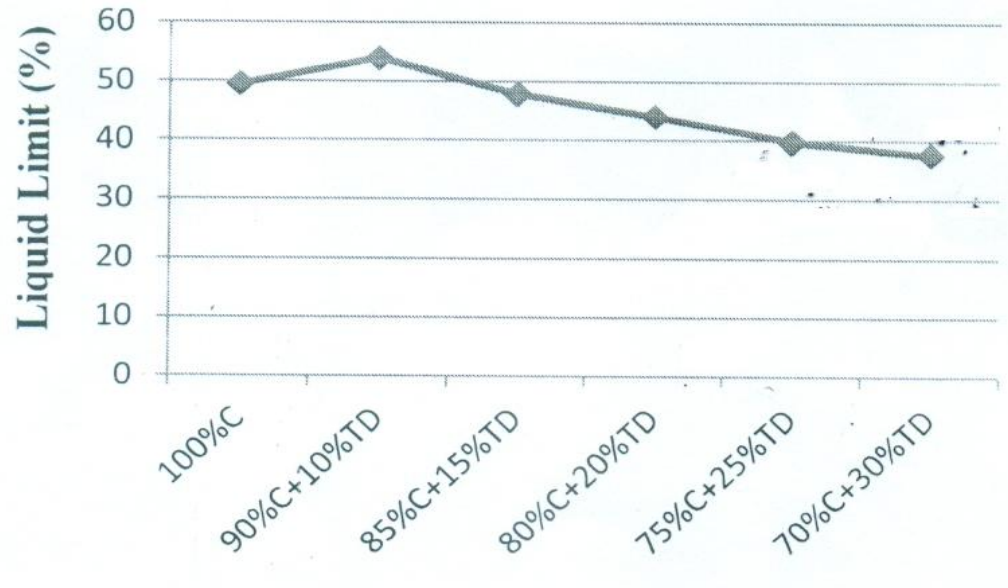

Percent Stabilizer added

Fig. 2: Effect of Processed Termite on the Liquid Limit Value of Sample C 


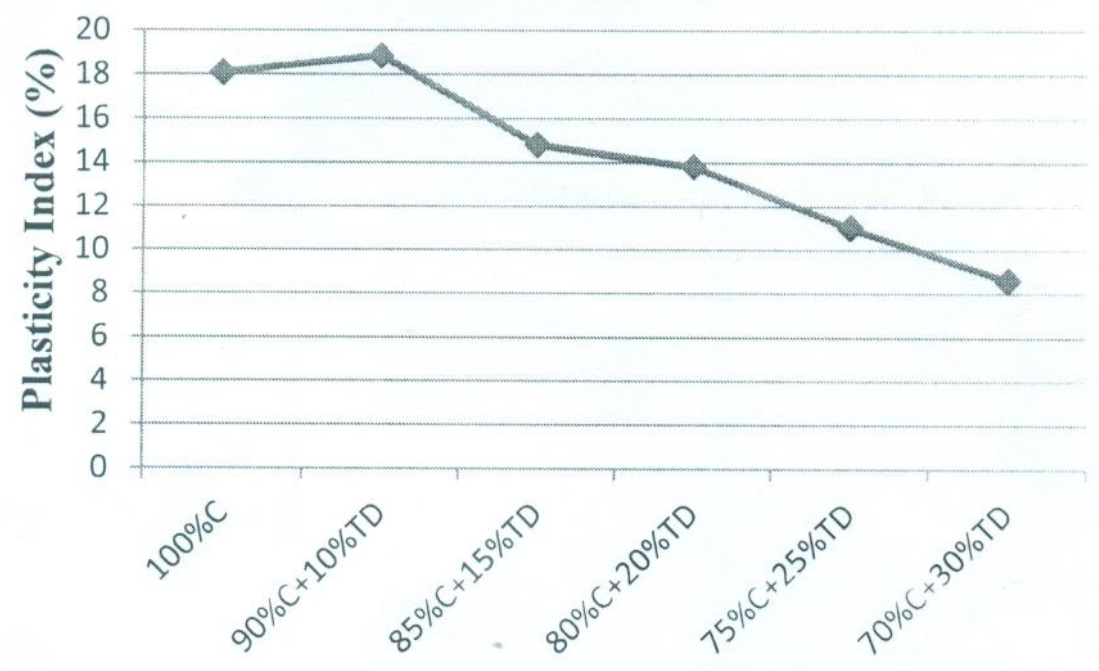

Percent Stabilizer added

Fig. 3: Effect of Processed Termite on the Liquid Limit Value of Sample C

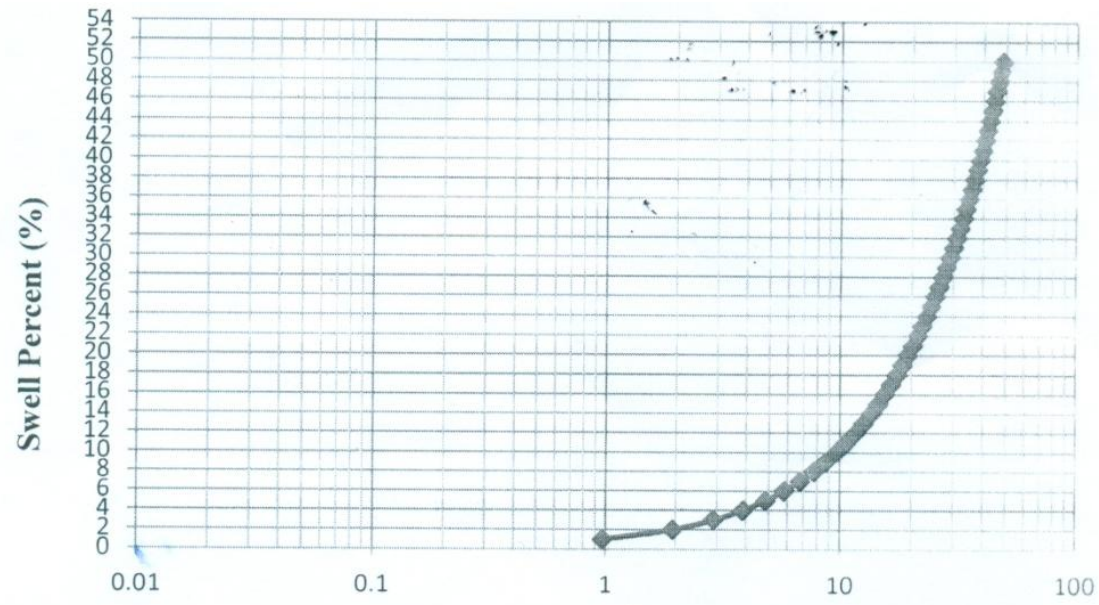

Time (minutes)

Fig. 4: Swell Percentage versus Time Relationship for sample C

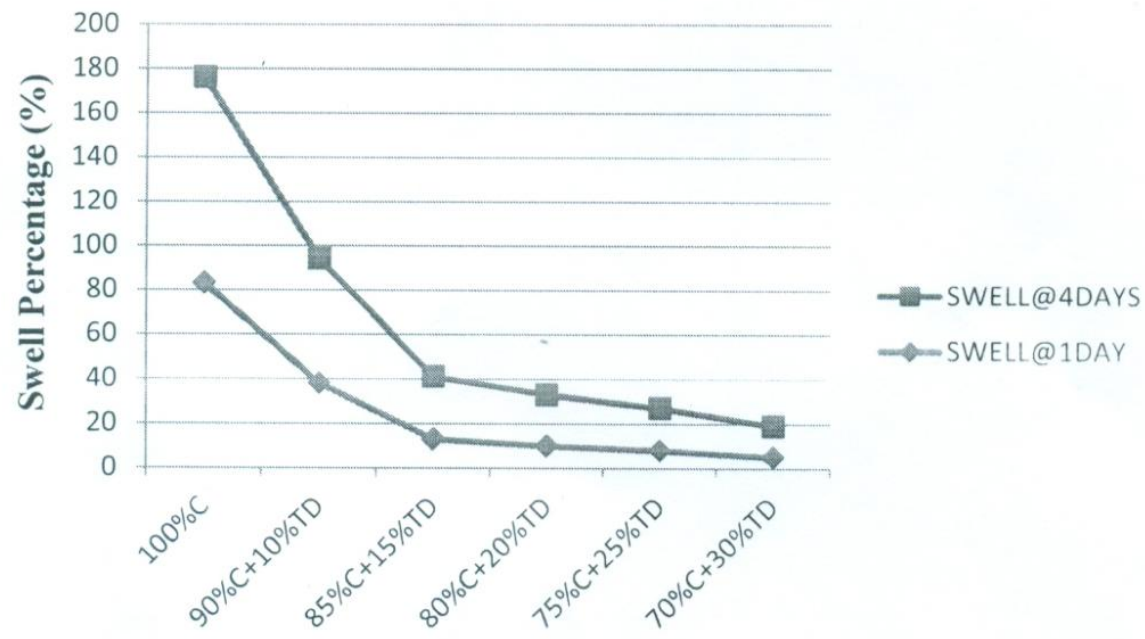

Percent Stabilizer added

Fig. 5: Effect of Curing on Swell Percentages 


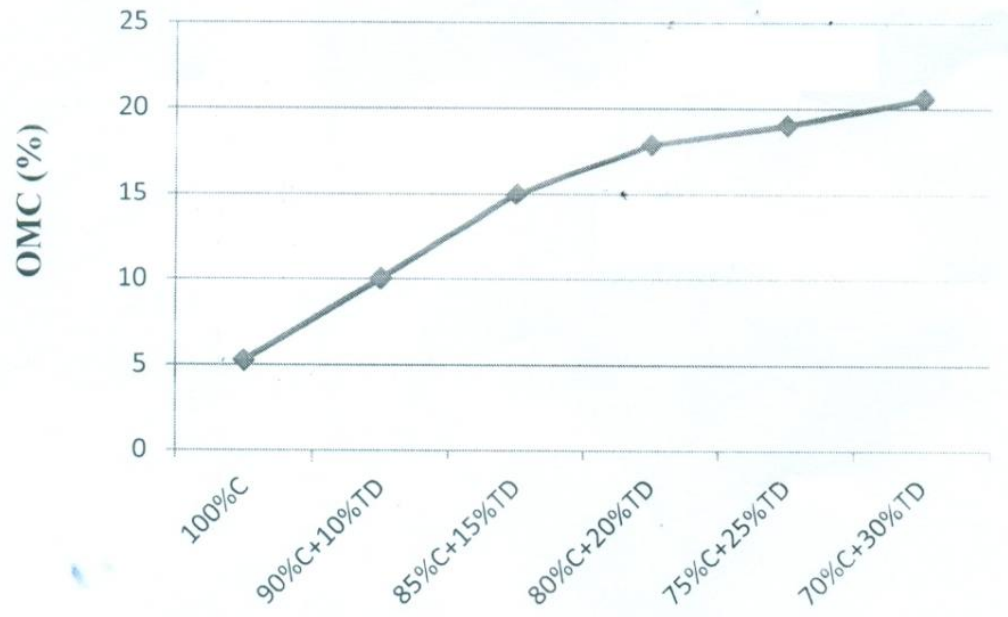

Percent Stabilizer added

Fig. 6: Variation of OMC with Processing Termite Added Sample

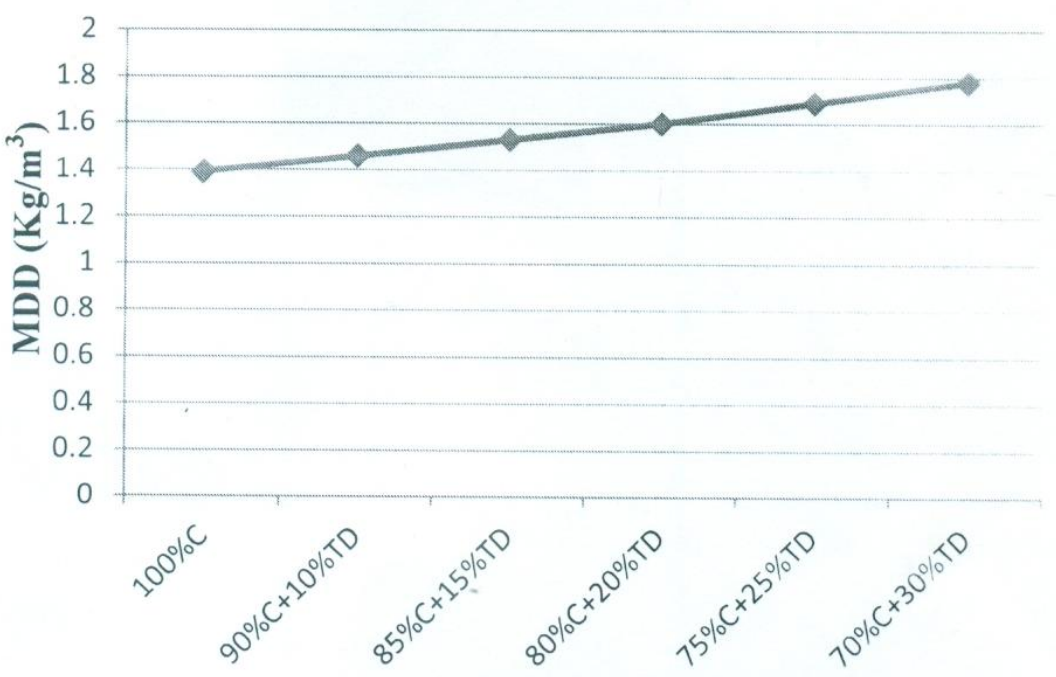

Percent Stabilizer added

Fig. 7: Variation of MDD with Processing Termite Added Sample

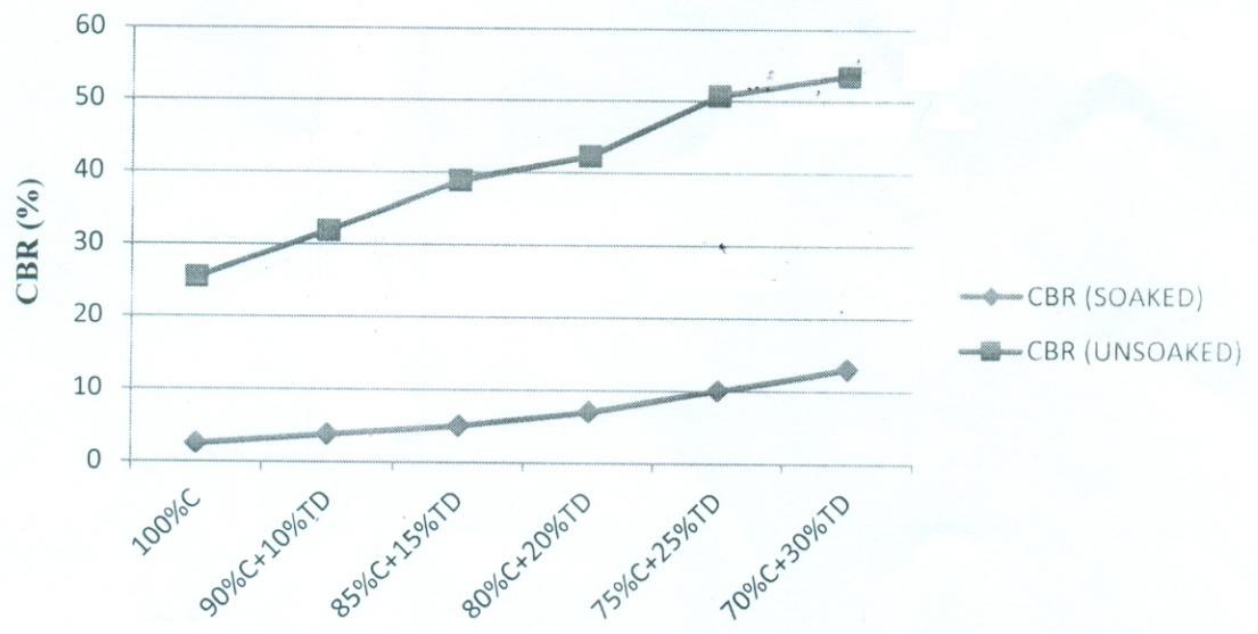

Percent Stabilizer added

Fig. 8: Effect of CBR with Processed Termite Added Sample 


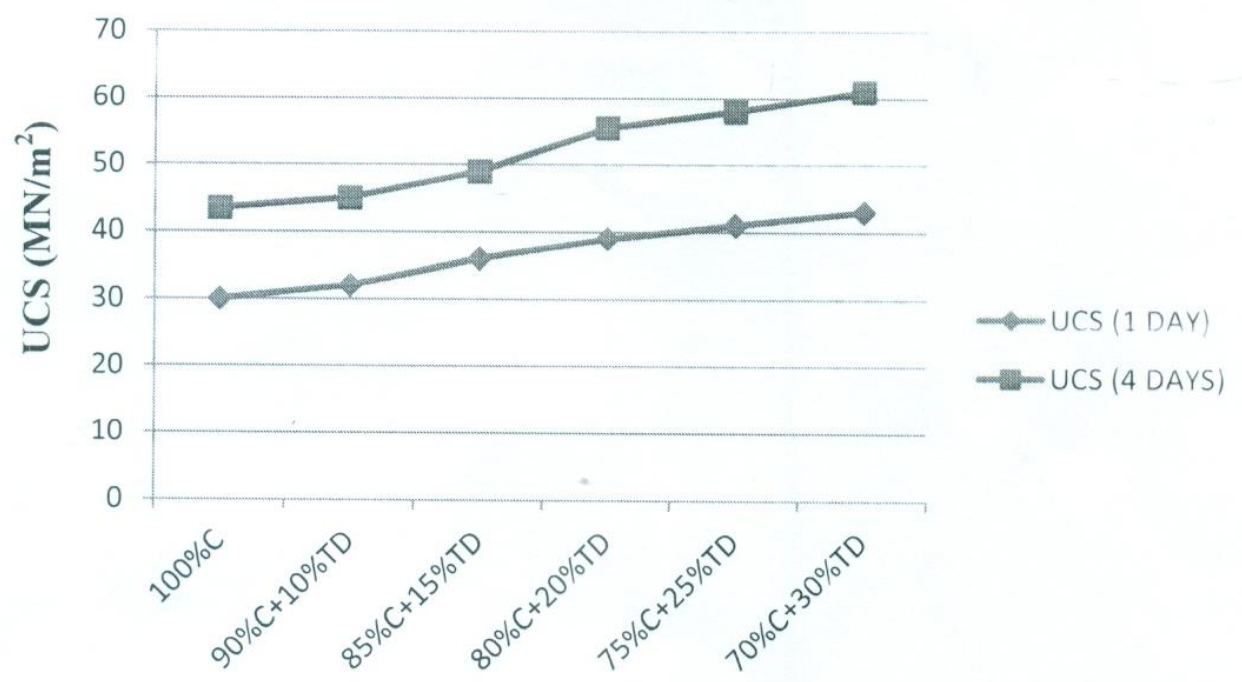

Percent Stabilizer added

Fig. 9: Effect of UCS with Processed Termite Added Sample

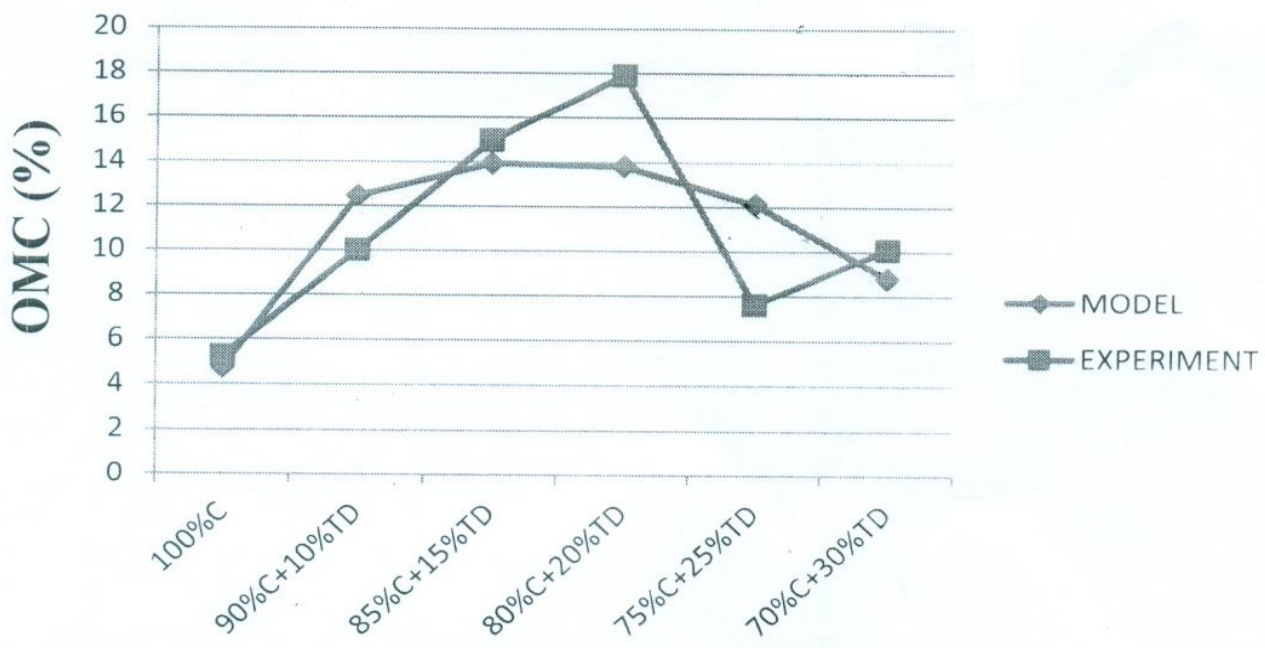

Percent Stabilizer added

Fig. 10: Graph of OMC against Percent Stabilizer

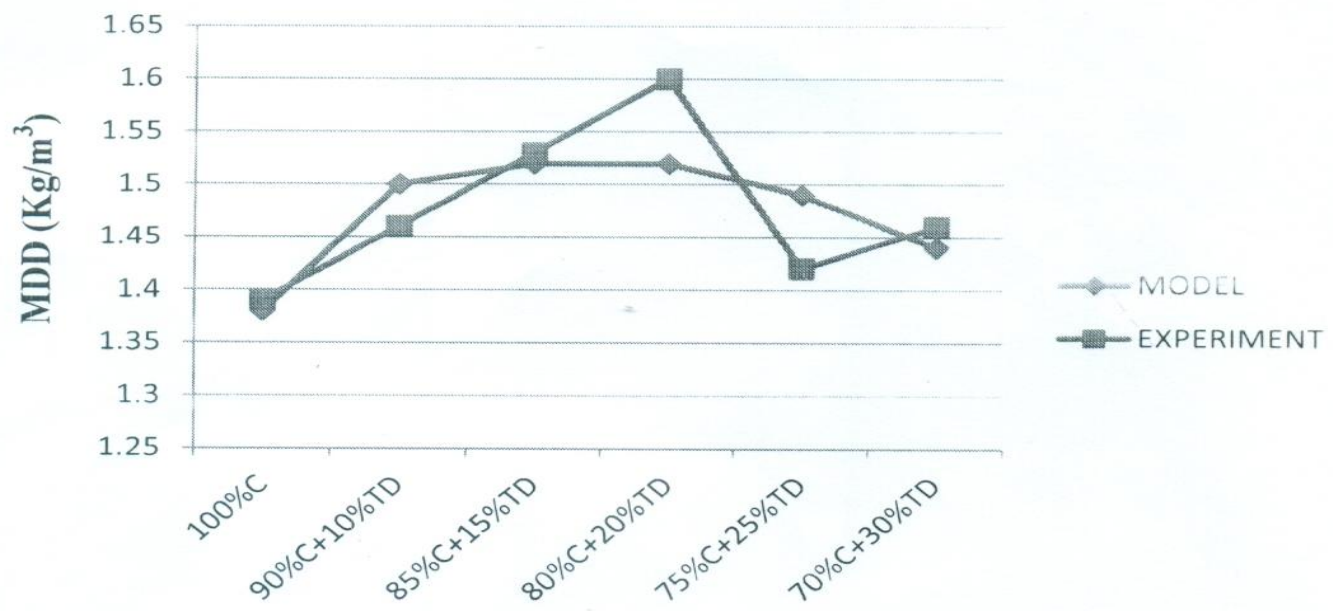

Percent Stabilizer added

Fig. 11: Graph of MDD against Percent Stabilizer 


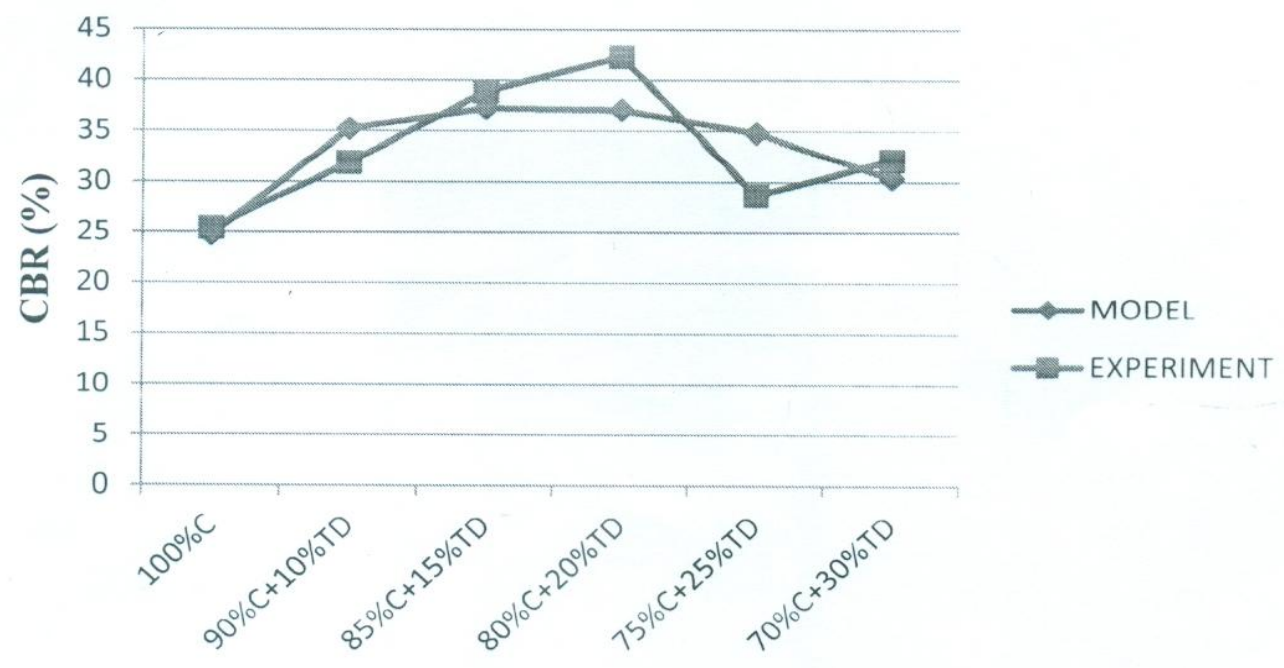

Percent Stabilizer added

Fig. 12: Graph of CBR (ubsoaked) against Percent Stabilizer

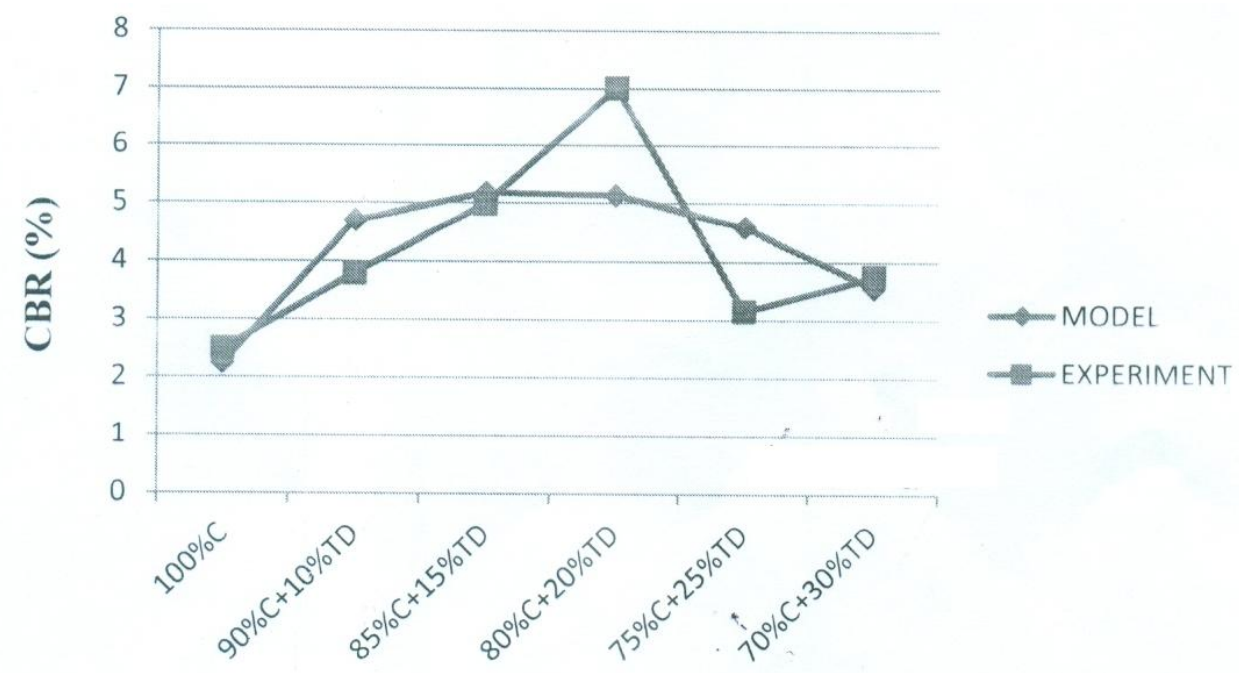

Percent Stabilizer added

Fig. 13: Graph of CBR (ubsoaked) against Percent Stabilizer

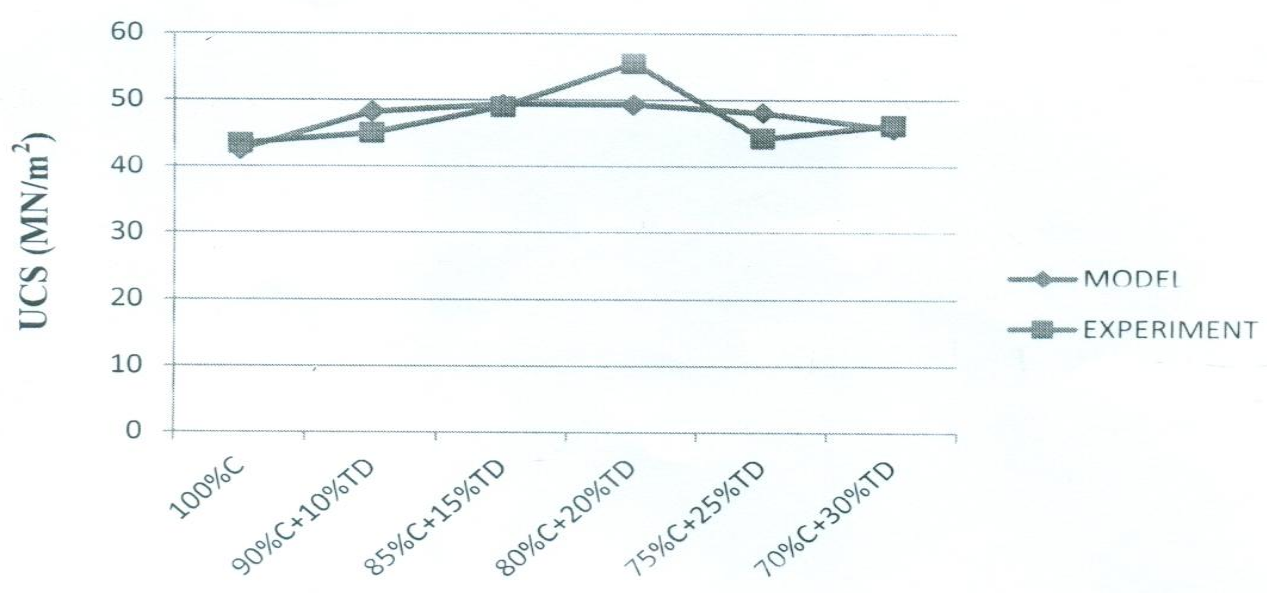

Percent Stabilizer added

Fig. 14: Graph of UCS (4 days) against Percent Stabilizer 


\section{Unconfined Compressive Strength}

Unconfined Compressive Strength (UCS) is the most common and adaptive method of evaluating the strength of stabilized soil. The results of variation of UCS with Increase In termite dust is shown in Figure 9. The UCS increases as the percentage of termite dust added sample increases from $0 \%$ to $30 \%$. This may be attributed to the formation of some calcium silicate compounds between the calcium hydroxides present in the soil and the processed termite

\section{Modeling of Strength Indices and Model Verification}

Scheffe's predictive mixture models. Scheffe, H. (1958) were formulated for CBR (soaked and unsoakcd) and 4-days UCS. The correlation between the experimented and the model results were computed for $r= \pm$ and the $t$ - test was used to verify the significance of $r$ at $5 \%$ level. This was done to facilitate the application of laboratory results and serve as a guide in predicting relationship between variables and also reduce the rigorous laboratory work by facilitating prediction of results. Figures $10-14$ shows the plots of the experimental and predicting models from equations (1 - 3) developed. The models were those for C'RR soaked. unsoakvd and UCS.

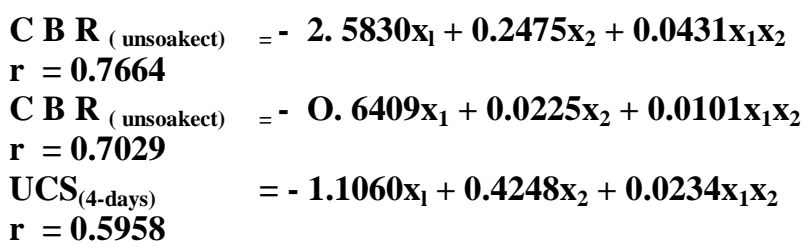

here $x_{1}=\%$ processed termite and $x_{2}=\%$ soil sample.

\section{Conclusions}

1. The result shows the combined percentage of $\mathrm{SiOz}, \mathrm{AI}_{2} \mathrm{O}_{3}$ and $\mathrm{Fe}_{2} \mathrm{O}_{3}$ to be 94.8 which satisfies the ASTM ASTM requirement of pozzolanic material of minimum of $70 \% \mathrm{MgO}$ composition was found to be 0.03 which is less than $4 \%$ maximum requirement. While $\mathrm{CaO}$ composition was $5.04 \%$ and is within the recommended range of ASTM (618-78. The loss on ignition value obtained was $5.02 \%$ which is less than $7 \%$ maximum required for pozzolan. It means that most of the samples were absorbed by the system and samples contain very little carbon.

2. The soil sample used in this experimental study was classified as A - 7 - 6 according to AASHTO classification system. Although in its natural state the soil is not suitable as filled material

3. The MDD and OMC generally increased from $1.39 \mathrm{Kg} / \mathrm{m}^{3}$ to $1.46 \mathrm{Kg} / \mathrm{m}^{3}$ and $5.2 \%$ to $10.10 \%$ respectively with increase in termite dust content from $0 \%-30 \%$.

4. The addition of termite dust from $0-30 \%$ also brings about a decrease in the liquid limit from $49.57 \%$ to $37.5 \%$, plastic limit from $31.5 \%$ to $29.09 \%$ and plasticity Index from $18.07 \%$ to $8.6 \%$.

5. The CBR and UCS of the soil are improved from $25.40 \%$ to $53.45 \%$ (unsoakcd) and $205 \mathrm{MN} / \mathrm{m} 2$ to $393 \mathrm{MN} / \mathrm{m} 2$ respectively as the percentage stabilizer increases from $0 \%$ to $30 \%$.

6. Models developed correspond with experimental results to a reasonable degree of accuracy and could be successfully used to predict the soil - termite dust properties in the absence of experimental data for soil.

\section{Acknowledgement}

The Author acknowledged the Almighty God for wisdom and knowledge. And also to my dear wife, Mrs. Aniema Samuel, Parents and Prof. F. O. Okakor .

\section{References}

[1]. Al-Rawas, A. A., Taha, R, Nelson, J. D. AI-Shap, T. B; and Al-Siyabi. H .. 2002. Comparative Evaluation of Various Additives Used -in. Stabilization of Fx pnnsi, Soils", Geotechnical Testing Journal, Vol. 25, No.2, pp. 199-209.

[2]. Abbadie L. and Lepage M., (1989), The role of subterranean fungus comb chambers (Isoptera, Maaotermitinae) in soil nitrogen cyding in a preforest savanna (COte d1 voire), Soil BioI. Biochem, 21 pp 1067-1071, Ivory Coast.

[3]. Abe 5.5., Yamamoto S. and Wakatsuki T. (2009). Physicochemical and morphological properties of termite (Maaotermes bel/ioosus) mounds and surrounding pedons on a toposequence of an inland valley in the southern Guinea savanna zone of Nigeria, Soil Science and Plant Nutrition 55, 514-522.

[4]. Adekayode F. O. and Ogunkoyam O. (2009) Comparative study of clay and organic matter content of termite mounds and the surrounding soi Department of Crop, Soil and Pest Management, Federal University of Technology, Akure, Nigeria. African Crop Science Conference Proceedings, Vol. 9. pp. 365 - 369

[5]. African Crop Science Conference Proceedings, Vol. 9. pp. 379 - 384 ISSN 1023-070X/2009

[6]. Amarjit S. (1967), Use of lime-fly ash in soil stabilisation for roads, JI. Of Indian Roads Congress, vol-XXX-1,143.

[7]. Anusha R., ArveeSujil J. and Sreedevi c., (2010), Chemical and Geotechnical Properties of Termite Mounds and Surrounding Soils, Report submitted to the Department of Ovil Engineering, College of Engineering Trivandrum, India. 
[8]. Arshad M.A., (1982), Influence of Marcrotennes michadson (sjost) on soil Fertility and vegetation in a semi arid savanna. Agro-Ecosyst., 8: $\quad$ 47-58.available at http://www.itc.nl/ ossiter/Docs/FM5-410/FM5-410_Ch9.pdf. accessed September 18 th 2013.

[9]. ASTM C618-78 Standard Specification for Coal Fly Ash and Raw or Calcined Natural pozzolan for use in Concrete.

[10]. BS 1377. Methods of Testing Soils for Civil Engineering Purpose. British Standard Institute, London, 1990

[11]. Bell F.G., (1993), Engineering treatment of soils, E \&FN Spon Publi rs, London. Bhoominathan A. and Hari 5.,(1999), Behaviour of fly ash under. static and cydic loading, Proc.of Indian Geotechnical Conference, Calcutta,pp.324- 326.

[12]. Bignell D. E., Oskarsson H. and Anderson J. M., (19801 Distribution and Abundance of Bacteria in the Gut of a Soil-feeding Termite ProcubitermesabUriensis (Termitidae, Termitinae), Journal of General Miaobiology.117, Pgs 393-403.

[13]. Bignell D.E., Oska n H. and Anderson J.M (1980). Distribution and Abundance of Bacteria in the Gut of a Soil-feeding Termite Procubitermesaburiensis (Termitidae, Termitinae). Joumal of General Microbiology. 117, 393-403.

[14]. Biju P. B., and Veeraragavan A., (2003), Soil Stabilisation using bio-enzyme for Rural Roads, (IRC Seminar: Integrated Development of Rural and Arterial Road Networks for Socio-Economic development), New Delhi, India.

[15]. Bruinsma O. H., (1979), An analysis of building behaviour of the termite Macrotermes subhyalinus, Ph.D. Dissertation, Landbouwhoge school, India Eutick M. L, O'Brien and Siaytor M., (1978), Bacteria from the Gut of Australian Termites, Applied and Environmental Microbiology, Pgs 823-828.

[16]. Eze-Uzomaka, O. J. and Agbo, D. (2010), "Suitability of Quarry Dust as Improvement to Cement Stabilized Laterite for Road Bases" Electronic Journal of Geotechnical Engineering, Vol. 15 (K), pp. 1053-1066

[17]. Fredlund, D. G., "Consolidometer Test Procedural Factors Affecting Swell Properues, Proceedings of the Second International Conference on Expansive Clay \& M Press, 1969, pp.435-456.

[18]. Fredlund, D. G. and Rahardjo, H. (1993), Soil Mechanics for Unsaturated c.; Jil ' . John Wiley and Sons'Inc., 517 pages

[19]. Hirofumi W., Masatoshi N., Gaku T., Ikuo Y., Andrew M., Scrivener and Hiroaki N. (1996), Site of Secretion and Properties of Endogenous Endo-/3-1,4-GluCiJnase Components from Reticulitermes speratus (Kolbe), a Japanese Subterranean Termite Elsevier Science Ltd, Britain.

[20]. Iilhan C. and Gye-Chun c., (2011), Strengthening of Korean residual soil with P-1,3/1,6-gluCiJn biopolymer, Elsevier Ltd, Korea

[21]. I1se lo Ackermana, Wenceslau G. Teixeirab, Susan J. R., Johannes loand Erick C.M.,(2007), The impact of mound-building termites on surface soil properties in a secondary forest of Central Amazonia, Department of Crop and Soil Sciences, Cornell University, Ithaca, NY 14853, USA

[22]. Jouquet P., Tessier D. and Lepage M. (2003), The soil structural stability of termite nests: role of days in Maaotermes bellicosus (Isoptera, Macrotermitinae) mound soils, European Journal of Soil Biology, Vol 2, Issue 7, pp 23-29

[23]. Lepage M., Abbadie t., Konate S., Merdad K. and OuedraOgo P., (1989), Structures related to termite activity and organic matterdynamics at different spatio-temporal scales, Laboratoire d'Ecologie, Paris, France.

[24]. lopez D. H., (2001), Nutrient Dynamics (C, Nand P)in termite mounds of Nausutitermes ephratae from Savannas of the Orinoco Uanos, Venezuela

[25]. Mihai O. M., Hozatski R. Clyne R. T. and Velasquez R., (2005), Preliminary Investigation of Enzyme Solutions as Soil Stabilizer, University of Minnesota, USA.

[26]. Mithanthaya I. R. and Ravishankar A. U., (2011), Laboratory Studies on Bio-Enzyme StDbilized Lateritic Soil as a Highway Material, Report submitted to Department of Civil Engineering NITK-Surathkal, India.

[27]. Muntohar, A. S., Hantoro, G., (2000), "Influence of Rice Husk Ash and Lime on Engineering properties of a Clayey Subgrade", Electronic Journal of Geotechnical Engineering Vol. 5, pp. 1-9

[28]. Minjinyawa, Y., Lucas, E. B. and Adegunioye, F. O. (2007), "Termite Mound Clay as Material for Grain Silos Construction", Agricultural Engineering International. The CIGR E-Journal Manuscript BC 07 002. Vol. IX.

[29]. Nakashima K., Watanabe H., Saitoh H., Tokuda G. and Azuma J., (2002), Dual cellulose-digesting system of the wood-feeding tennite,Coptotermes formosanus Shiraki, Insect Biochem.

[30]. Ndaliman M., (2006), Refractory Properties of Tennite Hills under Varied Proportions of Additives, Department of Mechanical Engineering, Federal University of Technology, Minna Nicola T. G., (2010), Structure and function of salivary reservoirs of the eastem Subterranean tennite, reticulitennes flavipes (kollar), The Ohio State University, USA.

[31]. Okakor, F. O. and Okomkwo, U. N. (2009), "Effects of Rice Husk Ash on Some Geotechnical Properies of Lateritic Soil, Leonardo Electronic Journal of Practices and Technologies, Vol 15, pp. 67-74

[32]. Okarfor, F. O. and Egbe, E. A. (2013), "Potentials of Cement Kiln Dust in Sub-grade Improvement", Nigerian Journal of Engineering Science and Application (JESA), Vol. 7, No. 1, pp. 36-47

[33]. Pomeroy D. E., (1977), The Distribution and Abundance of Large Tennite Mounds in ganda, Journal of Applied EcOlogy, Vol. 14, No.2, Uganda Popoola K. O. K. and Opayele A. V., (2012), Morphometries of Maaotermesbellicosus (African mound tennite) (Blattodea:Tennitidae) and the Impact of its Saliva Amylase on the Strength of Tennitarium Soil, Entomology unit, Department of Zoology, University of Ibadan, Dyo State, Nigeria.

[34]. Resh V. H. and Carde R. T., (2009), Encyclopedia of Insects, Academic Press New York, USA.

[35]. Scholen D. E. (1992), Nonstandard Stabilizers, Report FHWA-FLP-92-011, Federal Highway Administration, Washington, D.C, USA. Tewari and Yadu B. (1990), Thermodynamics of IndustriaJly-Importa (lt; Enzyme-catalyzed Reactions. Applied Biochemistry and Biotechnology. 23; 187-203.

[36]. Scheffe, H. (1958), "Experiment with Mixtures", Journal Of Royal Statistical Society, Series B, Vol. 20, pp. 344-360

[37]. Varma A. K. and Jaishree P., (1992), Glycoprotein components of cellulase and xylanase enzymes of a Badllus sp. Biotechnology letters vol, 14; 07-212

[38]. Varma A., Bala K. K., Jaishree P., Shailendra S. and Helmut K.,(1992), Ugnocellulose Degradation by micro organisms from termite hills and termite guts, School of life sciences, Jawaharlal University, India

[39]. Wood T. G., Johnson R.A. and Anderson J.M., (1983), Modification of soils in a Nigerian savanna by soil-feeding Cubitermes (Isoptera, Termididae). Soil BioI. Biochem. 15; 575-579, 